3 метою управління безпечністю розроблених борошняних виробів з органічної сировини, використовуючи принципи системи НАССР, створені дві рещептури тістечок «Космік» та «Лунік». У рецептурі тістечка «Космік» застосована органічна сировина: борошно рисове, імбир молотий, порошок лемонграсу, иукор кокосовий, масло верикове та обліпихова олія, меланж курячих яєць, варення чорноплідної горобини. У рецептурі тістечка «Лунік» використано борошно рисове у поєднанні із борошном зі спельти, порошок лемонграсу, иукор кокосовий, масло верикове та обліпихова олія, меланж курячих яєць, варення з ожини органічне. Розроблені продукти мають високі органолептичні властивості, що підтверджено відповідними дослідженнями. Визначені мікробіологічні та токсикологічні показники безпечності готових виробів. Вони не перевииують допустимих меж. Оскільки y розроблених зразках замінено жирову основу у порівнянні з контрольною рецептурою, було досліджено жирнокислотний склад виробів. Вміст насичених жирних кислот в обох зразках зменшився майже вдвічі, тоді як вміст мононенасичених жирних кислот зріс у зразку «Космік» в 1,78 рази, а у зразку «Лунік» у 1,8 рази. Збільшився вміст поліненасичених жирних кислот у 2,08 рази у обох зразках. Жирнокислотний склад виробів порівняно зі складом «ідеального ліпіду». Складено блок-схему виробництва яка є базою для аналізу небезпечних факторів. Проаналізовані небезпечні фактори виробництва борочняних кондитерських виробів. Запропоноване використання щоденних листів безпечності. Для відбору постачальників розроблена система ранжування.

Ці результати вказують на те, що використання органічної сировини $у$ виробництві тістечок дає змогу розширити існуючий асортимент борочняних кондитерсвких виробів. Додавання до ліпідної основи виробу нетрадиційних олій дає змогу поліпшити жирнокислотний склад. Отримані результати можуть використовувати підприємства кондитерсъкої промисловості 3 метою виробництва нових видів продукції та впровадження системи управління безпечністю харчових продуктів

Ключові слова: система управління безпечністю, жирнокислотний склад, борошняні кондитерсъкі вироби, вміст токсичних елементів

$\square$
UDC 664.681

DOI: $10.15587 / 1729-4061.2020 .195176$

\section{MANAGING SAFETY OF THE DEVELOPED CAKES MADE FROM ORGANIC RAW MATERIALS WITH IMPROVED FATTY-ACID COMPOSITION}

A. Tk achenko

$\mathrm{PhD}$, Associate Professor* E-mail: alina_biaf@ukr.net

I. S yrok h man

Doctor of Technical Sciences, Professor Department of Commodity Science, Technologies and Food Quality Management***

Y. B a s o v a

$\mathrm{PhD}$, Associate Professor*

A. Kobischan

$\mathrm{PhD}$, Associate Professor*

A. Artemenko

$\mathrm{PhD}$, Associate Professor Department of International Economics**

K h . Kovalchu k PhD, Associate Professor****

O. Ka la sh n y k

$\mathrm{PhD}$, Associate Professor

Department of Entrepreneurship and Law Poltava State Agrarian Academy Skovorody str., 1/3, Poltava, Ukraine, 36003

M. K a truk $\mathrm{PhD}$

Department of Entrepreneurship and Marketing

Ukrainian Academy of Printing

Pid Holoskom str., 19, Lviv, Ukraine, 79020

R. Z a k harch y n

$\mathrm{PhD}$, Associate Professor $* \star \star * *$

V. Havry lys h y

PhD, Associate Professor

Department of Commodity Science, Technology and

Quality Management of Food Products***

*Department of Commodity Research, Biotechnology, Examination and Customs**

**Poltava University of Economics and Trade

Kovalia str., 3, Poltava, Ukraine, 36000

*** Lviv University of Trade and Economics

Tuhan-Baranovskoho str., 10, Lviv, Ukraine, 79005 $* * * *$ Department of Commodity Research and Commodity Expertise

Lviv Institute of Economy and Tourism

Mentsynskyi str., 8, Lviv, Ukraine, 79007

Copyright (c) 2020, A. Tkachenko, I. Syrokhman, Y. Basova, A. Kobischan, A. Artemenko, Kh. Kovalchuk, O. Kalashnyk, M. Katruk, R. Zakharchyn, V. Havrylrshyn This is an open access article under the CC BY license (http://creativecommons.org/licenses/by/4.0)

\section{Introduction}

A serious challenge for modern people is the presence of harmful substances in foods. These include pesticides, nitrates, growth hormones, as well as other compounds, that are specifically added during production. However, it is scientifically proven that the production system does not cause food poisoning outbreaks. Their main reason is food process- 
ing aspects, such as nutritional supplements, the presence of mycotoxins from the use of growth hormones in livestock production [1]. Therefore, the important scientific issue is the creation of products and the organization of its production so that the products do not cause harm to the end consumer. The implementation of the HACCP system is exactly the tool that can guarantee the safety of finished products to the end consumer. Food safety management system, based on the principles of HACCP, has been recognized around the world; however, some difficulties are related to the mechanism of its introduction into production. Therefore, when developing new products, it is important to immediately consider the principles of safety management in production.

An important factor influencing the safety of the final product is the raw material from which it is made. Numerous scientific studies prove that organic raw materials are safer to produce finished foods. One can assume that the use of organic raw materials for the development of finished flour products would help improve their safety indicators. Based on the definition by European regulations, organic production is a holistic system of economic and food production [2]. Organic production implies the refusal to use agrochemicals, which positively influences the indicators of safety and reduces the risks of chemical hazardous factors.

It is scientifically proven that organic foods are healthier compared to conventional ones. This is influenced by a higher content of bioactive compounds (for example, polyphenols, vitamin $\mathrm{C}$, and carotenoids) and polyunsaturated fatty acids (PUFA). In addition, organic products contain fewer pesticides, whose content can be associated with dysbacteriosis and immune disorders and toxicity in humans. However, the results of health monitoring, reported by some studies, can also be closely related to lifestyle and observance of healthy lifestyles [3]. Therefore, the issue of the impact of organic products on the human body has not yet been studied enough. Despite this, during the development of new products, significant attention should be paid to the research into the biological value of new foods. There are data that prove higher biological value of organic products in comparison with traditional ones. This necessitates additional research, in particular concerning comparison of fatty acid composition of ordinary and organic products.

The relevance of work in this direction is the need to expand the range of flour confectionery products with improved consumer properties. Since there is a growing demand for organic products in the world, those studies are important that aim to develop flour products from organic raw materials. According to preliminary scientific data, it was established that organic raw materials are not only better in terms of safety indexes, but also in their content of micronutrients. That is why this paper reports our study into the fatty acid composition of products in which the lipid base is replaced with organic butter in combination with organic vegetable oil. As the issue of food safety in the world today is very acute, the study has suggested approaches to the development of new flour-based products, taking into consideration the principles of HACCP.

\section{Literature review and problem statement}

Statistics indicate significant dynamics of food poisoning not only in Ukraine, but in the whole world. WHO estimates that 600 million - almost 1 in 10 people in the world - get sick after the use of contaminated food, and 420,000 die every year, resulting in the lost 33 million years of healthy life. Children under the age of 5 account for $40 \%$ of severe diseases due to food products, which is 125,000 deaths each year. Laxative disease, the most common disease resulting from intake of contaminated food, results in 550 million sick people, and 230,000 deaths each year [4].

According to the WHO, as early as 2004, the highest mortality from diseases caused by food poisoning (from 100 to 420 deaths in 1,000,000) was recorded in the Russian Federation, and the lowest - in the countries of South America and Australia [5].

According to global estimates, thirty-one dangerous factors in food products causes 32 diseases, including 11 diarrheic diseases, whose pathogens are 1 virus, 7 bacteria, 3 elementary. There are also 7 invasive infectious diseases (1 virus, 5 bacteria, 1 elementary), 10 worms and 3 chemicals that are especially dangerous for humans. The main microbiological agents of food poisoning are Staphylococcus aureus, Bacillus cereus, Clostridium perfringen, Vibrio cholerae, Enterotoxigenic E. Coli, Salmonella spp., Shigella spp. [6]. Being infected with Listeria leads to miscarriage in pregnant women or the death of newborn babies. Although disease incidence is relatively low, severe disease and lethal effects take place. Chemical risks also pose a significant threat in terms of food safety. Thus, researchers found a significant connection between the influence of pesticides and children's leukemia. People who use pesticides professionally have 50 percent higher risk of Parkinson's disease [7]. Therefore, the issue of minimizing chemical hazardous factors during food production is very important [8]. The possible solution of this scientific problem is to use in the production of food products the organic raw materials which differ in the smaller content of harmful substances. This is indicated by scientific data, which prove that some organic products contain fewer agrochemical residues and lower nitrate content than those traditionally grown. Moreover, the use of pesticides in traditional agriculture can increase the risk of reproductive disorders, diseases of the immune, endocrine, and nervous system, and the development of certain cancers. Children are exposed to more risk than adults [9]. Given this, expanding the market of finished organic food products is very promising. Since the market for organic products of primary production in Ukraine is rapidly developing, the question arises about the expansion of the range, in particular flour-based confectionery products. This conclusion can be drawn from data by the Ministry of Agrarian Policy and Food [10]. Thus, in Ukraine, there are over 420 operators of organic and transitional period, including 294 agricultural producers. Most organic operators in Ukraine are certified according to the EU Organic standard, which is equivalent to the EU $834 / 2007$ and $889 / 2008$ regulations, which is used for export of organic products as well as in the domestic market [11]. The above data emphasize the feasibility of expanding the range and developing new products from organic raw materials.

Since the significant segment on the food market is occupied by flour confectionery products, the research of developed products of this particular group is proposed. It is worth noting that consumers today opt not only for the quality and safety of food products, but also their biological value. An important role in human nutrition belongs to a sufficient amount and balance of fatty acids. According to [12], organic food products are more balanced in terms of the fatty acid composition. Similar data are reported in [13], indicating an 
improved fat-acid composition of Italian organic sour-milk products compared to traditional. However, the cited study considers mainly dairy products and eggs, not confectionery.

Study [14] found that the concentration of antioxidants, such as polyphenols, is significantly greater in organic crops and products based on organic crops. The concentration of phenolic acids, stilbenes, flavones, flavanols, and anthocyanins is $19 \%, 69 \%, 28 \%, 26 \%, 50 \%$, and $51 \%$ higher, respectively, than in traditional products. However, the cited study does not cover the differences in the fatty acid composition of organic and non-organic products.

The scientific literature has enough data about the fatty acid composition of vegetable oils and the expediency of their use in the confectionery industry. Thus, the unrefined coldpressed sea buckthorn oil is a valuable source of vitamin E. The oil is dominated by oleic, stearic, linoleic, and palmitic acids. Unconventional oil outperforms margarine for the content of polyunsaturated fatty acids. Their largest amount is demonstrated by linseed oil, whose content of PUFA is 5.38 times higher than the PUFA content in margarine. The content of polyunsaturated fatty acids in soy, pumpkin, and buckthorn oil is 4.69 ; 4.61 ; 4 times higher than that in margarine. However, all the above studies do not highlight the difference between the fatty acid composition of organic vegetable oils and those not organic. This necessitates making a comparison between the lipid composition of organic and non-organic fat-containing products [15].

\section{The aim and objectives of the study}

The aim of this study is to manage safety of the developed cakes made from organic raw materials with improved fatty acid composition.

This would make it possible to expand the range of safe organic flour-based products.

To achieve the set aim, the following tasks have been solved:

- to develop formulations for cakes from organic materials;

- to investigate safety indicators of the finished products;

- to determine the fat-acid composition of the developed products;

- to devise a procedure for choosing suppliers, to compile a production flowchart, and to analyze dangerous factors during the production of cakes.

\section{Materials and methods to study quality and safety of the developed products}

The objects of our research are the developed cakes "Kosmyk" and "Lunik". The technological study of the developed products, as well as their formulations, are described in detail in paper [16].

The HACCP system implementation is regulated by the guidelines adopted by the Commission of the Code of Alimentarius. The guidelines outline a system for analyzing hazardous factors and critical control points. The instructions also contain general recommendations for using the system, recognizing that the application details may vary depending on the production characteristics [17]. Before applying the HACCP system in any sector of the food chain, it is necessary to act in accordance with the general principles of the
Food Hygiene Code, relevant codes practices and relevant legislation on food safety. The methodology is based on the application of technical and scientific principles to the entire food production chain: from field (farm) to table [18]. The fatty acid composition was determined by a gas chromatography method at the gas chromatographer HP 6890 (Czech Republic). Among the microbiological indexes, we defined the following: mesophilic aerobic and optional anaerobic microorganisms; bacteria of the group of Escherichia coli. Mesophilic aerobic and optional anaerobic microorganisms, CFU in $1 \mathrm{~g}$, were examined by calculating colonies growing on solid nutrient medium after incubation at $30^{\circ} \mathrm{C}$. Bacteria of the group of Escherichia coli (coliforms) were determined by a method based on the properties of bacteria of the group of Escherichia coli (BGEC) to break down glucose and lactose. The identification of bacteria of genus Salmonella in food is based on identifying the characteristic growth of colonies on agarized differential-diagnostic environments, which have typical, for bacteria of the genus Salmonella, biochemical and serologic properties according to DSTU EN 12824:2004. In order to study the content of toxic elements in the new cakes, we used the generally accepted techniques: copper, zinc, lead, and cadmium were determined by an atomic-absorption method, arsenic - by a colorimetric method, mercury - by the method of flame-free atomic absorption [16].

Since the implementation of food safety management system implies that the main role belongs to the programs-prerequisites and operational daily control, to reduce the number of logs, it has been proposed to keep a daily safety sheet based on the principles [19] proposed by McDonalds.

The selection of suppliers, aimed to improve the level of safety, should be performed in line with a ranking method. The method implies ranking the suppliers based on the points assigned by experts according to a series of criteria.

\section{Results of studying the consumer properties of the developed cakes made from organic raw materials}

\subsection{Results of examining safety indicators of the} developed cakes

In order to expand the range of organic flour confectionery products, 2 formulations of sand cake, in the form of baskets with fruit fillings, were developed: "Kosmyk" and "Lunik". The "Kosmyk" cake formulation includes organic raw materials: rice flour, milled ginger, lemongrass powder, coconut sugar, butter, and sea buckthorn oil, chicken egg mélange, chokeberry jam. The "Lunik" cake formulation includes rice flour in combination with spelt flour, lemongrass powder, coconut sugar, butter, and sea buckthorn oil, chicken egg mélange, organic blackberry jam. Control sample is a basket of jelly and fruit made according to the traditional formulation. The main difference of the proposed samples is that they are made entirely of organic raw materials. Besides, the fat base of the control sample is margarine. For the developed samples, it is proposed to replace the fat base with butter and sea buckthorn oil. The technology of semi-finished sand cake product preparation consists of 4 stages: preparation of raw materials for production, preparation of a sand semi-finished product, shaping a semi-finished product, baking. In terms of the organoleptic parameters, the devised samples outperformed control. The study of organoleptic indicators of these products is reported in [16]. The summarized formulations for the developed semi-finished products are given in Table 1. 
Table 1

Summarized formulations for the developed sand semifinished products per $1 \mathrm{~kg}$ of finished product

\begin{tabular}{|l|c|c|}
\hline \multirow{2}{*}{ Raw material } & $\begin{array}{c}\text { Quantity, g, per } \\
1 \mathrm{~kg}\end{array}$ & $\begin{array}{c}\text { Quantity, g, per } \\
1 \mathrm{~kg}\end{array}$ \\
\cline { 2 - 3 } & 180 & 160 \\
\hline Organic rice flour & - & 25 \\
\hline Organic spelt flour & 50 & 50 \\
\hline Organic ground ginger & 40 & 40 \\
\hline Organic lemongrass powder & 540 & 550 \\
\hline Organic coconut sugar & 100 & 100 \\
\hline Organic butter & 10 & 10 \\
\hline Organic sea buckthorn oil & 250 & 250 \\
\hline Organic chicken egg mélange & 3.5 & 3.5 \\
\hline $\begin{array}{l}\text { Essence based on organic } \\
\text { lemon }\end{array}$ & 5 & 5 \\
\hline Salt & 2 & 2 \\
\hline Baking soda & 2 & 2 \\
\hline Ammonium carbon dioxide & 1,000 & 1,000 \\
\hline Yield & 1592.5 & \\
\hline Total & \multicolumn{2}{|c|}{} \\
\hline
\end{tabular}

It is worth noting that the content of toxic elements and aflatoxin $B_{1}$ is much lower than the normative values in the samples made from organic raw materials. This is due to the fact that agricultural chemicals are not used in the cultivation of organic products.

The values of microbiological indicators in the finished products are given in Table 3 , based on the results of our study.

Based on data in Table 3, all samples comply with the national standard of Ukraine for the content of microbiological indicators. No pathogenic microorganisms have been found either in the samples made from regular raw materials or in the samples made from organic raw materials.

The data of our study suggest that according to the content of toxic elements those products are safe that are made of organic raw materials, obviously because the organic raw materials are not contaminated with agrochemicals. The values of microbiological indicators do not correlate with the origin of raw materials (organic or traditionally grown). All microbiological indicators of the developed and control samples conform to the requirements of the standard.

Table 3

When developing new products, the focus is typically the organoleptic indicators and requirements of the national standard DSTU 4803:2007 "Cakes and pastries. General technical conditions". According to this standard, the physical appearance should be inherent in the product, the surface - uniform and baked, the shape - diverse, but without fractures. The products' assessment in terms of organoleptic indicators was described in detail in [16].

However, since we have already described the importance of the issue of food safety, we examined safety indicators of the developed products and compared them with the control sample (made from non-organic raw materials). Given that the products were made of organic materials, important indicators are the content of toxic elements and aflatoxin $\mathrm{B}_{1}$. Our study was conducted in accordance with the methods described in [16]. In particular, copper, zinc, lead, and cadmium were determined by an atomic-absorption method, arsenic - colorimetric method, mercury - by the method of flame-free atomic absorption, aflatoxin $\mathrm{B}_{1}-$ by a fluorescent method. The content of toxic elements in the studied samples is given in Table 2 .

Table 2

Content of toxic elements in the studied samples of cakes

\begin{tabular}{|c|c|c|c|c|}
\hline $\begin{array}{c}\text { Toxic ele- } \\
\text { ment title }\end{array}$ & $\begin{array}{c}\text { Permissible level, } \\
\mathrm{mg} / \mathrm{kg} \text {, not above }\end{array}$ & Control & «Kosmyk» & «Lunik» \\
\hline Lead & 0.5 & 0.5 & 0.2 & 0.1 \\
\hline Cadmium & 0.1 & 0.1 & 0.1 & 0.1 \\
\hline Arsenic & 0.3 & 0.3 & 0.1 & 0.1 \\
\hline Mercury & 0.02 & 0.02 & 0.001 & 0.001 \\
\hline Aflatoxin B & 0.005 & 0.004 & 0.003 & 0.003 \\
\hline
\end{tabular}

\section{2. Studying the fat-acid composition of cakes made from organic raw materials}

Numerous scientific studies prove that the fatty acid composition of organic products is better than that in regular products. Thus, based on 170 studies of milk, regular and organic, it was established that the concentration of total PUFA and n-3 PUFA was considerably higher in organic milk. The $\alpha$-linolenic acid concentration (ALA) in organic milk exceeded that in regular milk by $69 \%$ [21]. The study, conducted under the guidance of the European Commission, testifies that animal products, which are grown organically, contain a greater number of polyunsaturated fatty acids. However, as noted in the study, the reason for the better fat-acid composition of milk and beef is that the cattle grown in organic way consumes predominantly grass. At the same time, cattle grown in the traditional way mainly consumes grain, moreover, it often contains antibiotics and hormones [22].

Since the composition of the new cakes also included vegetable oils, characterized by improved fat-acid composition, we determined the content of fatty acids in the new samples. The results are given in Table 4.

Table 4 shows that the fatty acid composition of samples, due to the introduction of sea buckthorn oil, is better than the control sample. Thus, the content of saturated fatty ac- 
ids in both samples decreased by almost twice, whereas the content of monounsaturated fatty acids and polyunsaturated fatty acids on the contrary increased.

Table 4

Fatty-acid composition of cakes

\begin{tabular}{|l|c|c|c|}
\hline \multicolumn{1}{|c|}{ Fatty acid title } & Control & «Kosmyk» & «Lunik» \\
\hline Capric (C 10: 0) & 0.05 & 0.01 & 0.02 \\
\hline Lauric (C 12: 0) & 0.05 & 0.10 & 0.08 \\
\hline Myristic (C 14: 0) & 0.40 & 0.10 & 0.06 \\
\hline Pentadecanoic (C 15: 0) & 0.5 & 0.00 & 0.01 \\
\hline Palmitic (C 16: 0) & 2.63 & 2.10 & 2.35 \\
\hline Margaric (C 17: 0) & 0.59 & 0.01 & 0.02 \\
\hline Stearic (C 18: 0) & 1.48 & 0.65 & 0.45 \\
\hline Arachic (C 20: 0) & 0.15 & 0.03 & 0.00 \\
\hline $\begin{array}{l}\text { Total saturated fatty acids } \\
\text { (SFAs): }\end{array}$ & 5.85 & 3.00 & 2.99 \\
\hline Palmitoleic (C 16: 1) & 0.03 & 0.05 & 0.05 \\
\hline Oleic (C 18: 1) & 1.60 & 2.66 & 2.88 \\
\hline Erucic (C 22: 1) & 0.00 & 0.03 & 0.04 \\
\hline Gondic (C20: 1) & 0.00 & 0.11 & 0.02 \\
\hline Nervic (C 24: 1) & 0.00 & 0.01 & 0.01 \\
\hline Together with MSFAs & 1.60 & 2.86 & 3.12 \\
\hline Linoleic (C 18: 2) & 1.73 & 1.81 & 3.66 \\
\hline Linolenic (C 18: 3) & 0.06 & 1.90 & 0.02 \\
\hline Arachidonic (C 20: 4) & 0.01 & 0.05 & 0.06 \\
\hline Together with PUFAs & 1.80 & 3.75 & 3.74 \\
\hline
\end{tabular}

An important factor is the ratio of $\omega-6$ and $\omega-3$ acids in human diet. The ratio $\omega-6$ to $\omega-3$ of polyunsaturated fatty acids in the diet of a healthy person should be 4:1 to 2:1. However, the available data show the ratio of fractions of fatty acids, which is close to "perfect lipid" - 33.5/33.5/33 (SFA/MSFA/PUFA).

Based on data in Fig. 1, the ratio of fatty acid fractions is the worst, compared to "ideal lipid", for the control sample. In particular, this sample contains $63.24 \%$ of saturated fatty acids, which is almost twice higher than the recommended norm. The cake "Lunik" is the closest to "perfect lipid" according to its fatty acid composition and has the most rational ratio of fatty acids $-31.05 / 30.11 / 28.84$. This cake is also characterized by a high content of polyunsaturated fatty acids.

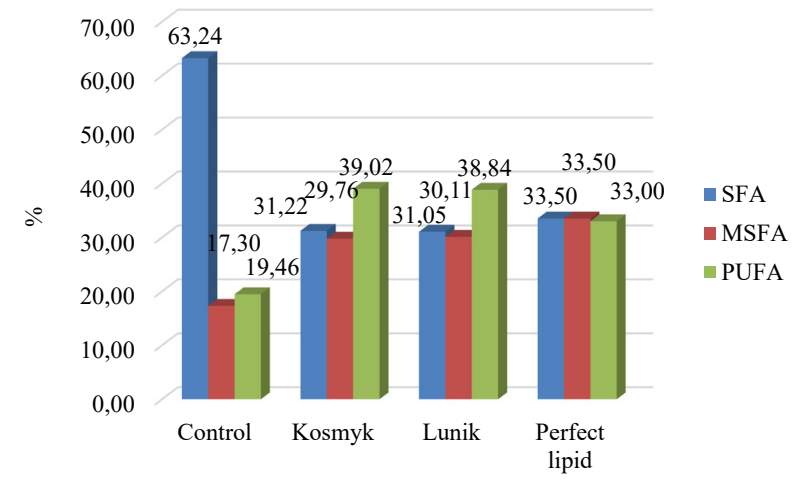

Fig. 1. Ratio of fatty acid fractions in cakes compared to "perfect lipid"

These data may indicate the prospects for replacing traditional raw materials with organic, as well as the expediency of using, in the production of flour confectionery products, butter in combination with vegetable oils.

5. 3. Compiling a supplier selection procedure, production flowchart, and analysis of hazardous factors in production of cakes

The implementation of the HACCP system is a complex step for each enterprise. According to the Codex Alimentarius guidelines, the HACCP plan should consist of 12 consecutive steps.

Before an enterprise begins to implement the HACCP system, it is necessary to develop and implement programs-preconditions that relate to hygienic processes. At this stage, one of the most important steps is the choice of suppliers. The proposed model for ranking the suppliers of raw materials is given in Table 5 .

All suppliers of raw materials are ranked. The most significant criteria for ranking organic product manufacturers is the availability of the State registration of the supplier, the implemented HACCP system, the availability of an organic certificate and the conformity of quality indicators to the requirements of normative documentation. If the score is less than 50 points, the supplier cannot qualify.

To analyze hazardous factors and to establish control critical points, a flowchart of production process is needed in order to verify it at production. To produce organic flour-based products, we have proposed a flowchart shown in Fig. 2.

An analysis of dangerous factors at each stage of the flowchart allows us to argue that the most dangerous, in terms of food safety, are the stages of procurement and product acceptance. That is why it is important to rank suppliers based on the proposed methodology described above.

Table 5

Assessment of suppliers to produce organic flour-based products

\begin{tabular}{|c|c|c|c|c|c|c|c|c|}
\hline Supplier & $\begin{array}{c}\text { Availability of state } \\
\text { registration of the } \\
\text { market operator } \\
\text { (with the relevant } \\
\text { type of activity) or } \\
\text { operating permit }\end{array}$ & $\begin{array}{c}\text { HACCP system } \\
\text { availability } \\
\text { audit, written } \\
\text { questionnaire, } \\
\text { certification) }\end{array}$ & $\begin{array}{c}\text { The pres- } \\
\text { ence of an } \\
\text { organic } \\
\text { certificate }\end{array}$ & $\begin{array}{c}\text { Conformity of the sup- } \\
\text { plied products with the } \\
\text { requirements of regulatory } \\
\text { documents and agreed } \\
\text { specifications, availability of } \\
\text { supporting documents }\end{array}$ & $\begin{array}{c}\text { Number of de- } \\
\text { liveries where } \\
\text { deviations were } \\
\text { detected }\end{array}$ & $\begin{array}{c}\text { Remoteness of } \\
\text { supplier from } \\
\text { production }\end{array}$ & $\begin{array}{c}\text { Total } \\
\text { points }\end{array}$ \\
\hline $\begin{array}{c}\text { Maximal } \\
\text { sum of } \\
\text { points }\end{array}$ & 10 & 10 & 15 & 15 & 5 & 0 & 5 & 0 \\
\hline
\end{tabular}




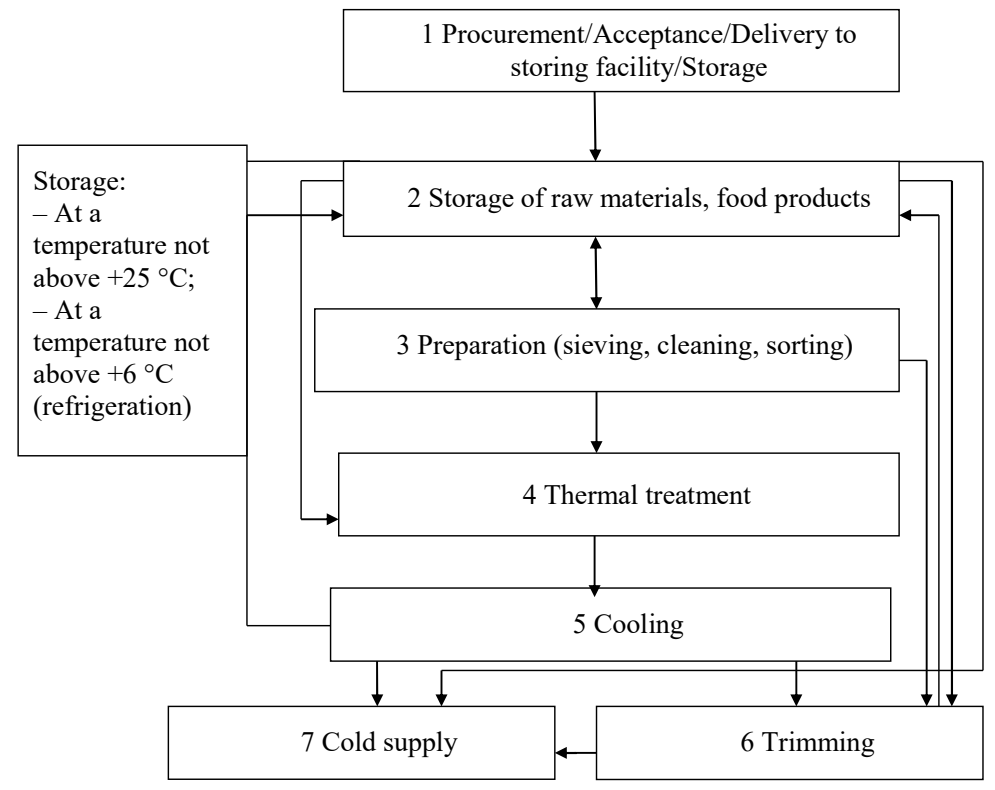

Fig 2. Flowchart of flour-based products manufacturing to introduce the HACCP system
Based on the compiled flowchart, we analyzed dangerous factors in the production of cakes from organic raw materials, given in Table 6 .

Thus, the most significant hazardous factors in the production of organic cakes are the ingress of glass when opening a glass container, the presence of pathogenic microorganisms after heat treatment and the presence of allergens in the products. That is why we have proposed keeping daily safety sheets, which include the monitoring of the aforementioned hazards.

Important factors of food safety observance are monitoring of temperature regimes, observance of rules of hygiene by personnel, cleanliness of working surfaces, control of glass objects. These hygienic processes are to be monitored daily. As regards the critical control points, a decision tree method was used to define them. A critical control point is a stage of "safety of food products", where it is important to ensure a measure to prevent, eliminate. or reduce the acceptable level of danger that threatens the safety of food products.

Table 6

Analysis of hazardous factors in the production of organic cakes

\begin{tabular}{|c|c|c|c|c|}
\hline Stage title & Hazardous factor & $\begin{array}{l}\text { Probability of occur- } \\
\text { rence, } B(\text { low } B=0.1 \text {; } \\
\text { medium } B=0.2 ; \text { high } \\
\qquad B=0.3 \text { ) }\end{array}$ & $\begin{array}{c}\text { Harmful impact } \\
\text { seriousness, } \mathrm{C} \\
\text { (low } \mathrm{C}=1 ; \text { medium } \\
\mathrm{C}=2 ; \text { high } \mathrm{C}=3)^{*}\end{array}$ & $\begin{array}{l}\text { Hazardous fac- } \\
\text { tor assessment } \\
\quad(K=\mathrm{B} \times \mathrm{C})\end{array}$ \\
\hline \multirow{4}{*}{$\begin{array}{l}\text { Acceptance of raw } \\
\text { materials, foodstuffs, and } \\
\text { materials }\end{array}$} & $\begin{array}{l}\text { Pathogenic micro-organisms, including } \\
\text { Salmonella, Listeria monocytogenes, } \\
\text { E. coli O 157:H7, St. aureus }\end{array}$ & Low $B=0.1$ & $\mathrm{C}=3$ & $K=0.3$ \\
\hline & Toxic substances in packaging materials & Low, $\mathrm{B}=0.1$ & $\mathrm{C}=2$ & $K=0.2$ \\
\hline & Foreign inclusions, stones, sand, stones, glass, etc. & Low, $B=0.1$ & $\begin{array}{l}\text { May cause disease, } \\
\mathrm{C}=2\end{array}$ & $K=0.2$ \\
\hline & Allergens & Low, $B=0.1$ & $\mathrm{C}=3$ & $K=0.3$ \\
\hline \multirow{3}{*}{$\begin{array}{l}\text { Storage of raw materials, } \\
\quad \text { food products } \\
\left(\text { at temperatures to }+25^{\circ} \mathrm{C} \text { ) }\right.\end{array}$} & \begin{tabular}{|c|} 
Pathogenic microorganisms, including Salmonella, \\
Listeria monocytogenes, E. coli O 157:H7, BGEC \\
sanitary-indicative microorganisms, MAFAM \\
\end{tabular} & Low, $B=0.1$ & $C=3$ & $K=0.3$ \\
\hline & Foreign inclusions & Low, $B=0.1$ & $C=3$ & $K=0.3$ \\
\hline & Allergens & Low, $B=0.1$ & $C=3$ & $K=0.3$ \\
\hline $\begin{array}{l}\text { Storage of raw materials, } \\
\text { food products at a tempera- } \\
\text { ture not higher than }+6^{\circ} \mathrm{C} \\
\end{array}$ & $\begin{array}{c}\text { Pathogenic microorganisms, sanitary } \\
\text { demonstration microorganisms BGEC, MAFAM }\end{array}$ & Low, $B=0.1$ & $C=3$ & $K=0.3$ \\
\hline $\begin{array}{l}\text { Storage of raw materials, } \\
\text { food products at } \\
\text { a temperature not higher } \\
\text { than }-18{ }^{\circ} \mathrm{C} \\
\end{array}$ & $\begin{array}{l}\text { Pathogenic microorganisms, } \\
\text { sanitary-demonstration microorganisms of } \\
\text { the BGEC, MAFAM }\end{array}$ & Low, $B=0.1$ & $C=3$ & $K=0.3$ \\
\hline \multirow[t]{2}{*}{ Preparation } & $\begin{array}{c}\text { Pathogenic microorganisms, sanitary } \\
\text { demonstration microorganisms BGEC, MAFAM }\end{array}$ & Medium, $\mathrm{B}=0.2$ & $C=3$ & $K=0.6$ \\
\hline & Glass when opening a glass container & High, $\mathrm{B}=0.3$ & $C=3$ & $K=0.9$ \\
\hline Thermal treatment & $\begin{array}{c}\text { Pathogenic microorganisms, sanitary } \\
\text { demonstration microorganisms BGEC, MAFAM }\end{array}$ & High, $B=0.3$ & $C=3$ & $K=0.9$ \\
\hline Cooling & $\begin{array}{c}\text { Spore microorganisms. Pathogenic microorgan- } \\
\text { isms, sanitary demonstration microorganisms } \\
\text { BGEC, MAFAM }\end{array}$ & Low, $B=0.1$ & $C=3$ & $K=0.3$ \\
\hline Trimming & $\begin{array}{c}\text { Pathogenic microorganisms, sanitary } \\
\text { demonstration microorganisms BGEC, MAFAM }\end{array}$ & Medium, $B=0.2$ & $C=3$ & $K=0.6$ \\
\hline \multirow{2}{*}{ Cool supply } & $\begin{array}{c}\text { Pathogenic microorganisms, sanitary } \\
\text { demonstration microorganisms BGEC, MAFAM } \\
\end{array}$ & Low, $B=0,1$ & $C=3$ & $K=0.3$ \\
\hline & Allergens & High, $B=0.3$ & $\begin{array}{l}\text { May cause serious } \\
\text { illness, } C=3\end{array}$ & $K=0.9$ \\
\hline
\end{tabular}

Note: ${ }^{*}-C=2-$ can cause disease $; C=3-$ may cause severe disease 
The HACCP system efficiency is characterized by the possibility of its implementation. Therefore, it is proposed not to burden the production process with critical control points (CCP) and to set a single CCP at the stage of thermal treatment. To simplify the recording procedure, it is proposed to keep a daily safety sheet, which includes records from checking several parameters, namely:

- admission of employees to work;

- monitoring of raw materials storage temperature;

- cleaning of working surfaces;

- control of glass objects;

- measurement of temperature inside the product.

Thus, the introduction of the HACCP system requires at all stages the participation of all qualified personnel involved in the production. In addition, a logical and adapted HACCP plan can help food market operators improve the level of food safety management [23]. It was established that the implementation of a safety management system implies a detailed analysis of dangerous factors, which includes the analysis of each stage in the production process. To ensure traceability and incremental character of the HACCP system, it is proposed to rank suppliers according to the predefined criteria. The management of daily safety sheets can be a solution to control the most dangerous hazards.

\section{Discussing the results of studying safety of the developed cakes made from organic raw materials}

In order to expand the range of organic flour-based confectionery products, 2 formulations of cakes with fruit fillers, "Kosmyk" and "Lunik", were developed, which in their composition contain genuine organic raw materials. Novelty of the proposed formulations is the fact that their composition includes only organic products, which promotes the expansion of the market of finished flour products. This study is a continuation of scientific work in the organic production of finished products in Ukraine. We have developed biscuits from organic raw materials and muffins from organic raw materials [24].

Among the microbiological parameters, we determined the content of MAFAM, BGEC, and bacteria of the genus Salmonella. The content of MAFAM was 100 and 100 CFU per $1 \mathrm{~g}$ for both developed samples; no other microorganisms were detected. All samples conform to the national standard of Ukraine for the content of toxic elements and aflatoxin $\mathrm{B}_{1}$. The data obtained confirm safety of the developed products. Promising in this direction are also clinical studies that are planned in the future. This relates to the scientific data on an experiment, which involved 14,000 children from $5 \mathrm{Eu}-$ ropean countries, aged 5-13, from families with anthroposophical lifestyle, which implies preference for organic (or biodynamic) food; fewer cases of allergies were detected [25].

It was established that the replacement of the lipid base with the combination of organic butter and sea buckthorn oil helps improve the fatty acid composition of the finished products. This confirms the results of the previous scientific studies reported in [26] concerning the improved fat-acid composition of organic products. Due to the replacement of the lipid base in the developed products, the content of saturated fatty acids in both samples decreased by almost twice, whereas the content of monounsaturated fatty acids increased, in the sample "Kosmyk", by 1.78 times, and, in the sample "Lunik", by 1.8 times. The content of polyunsaturat- ed fatty acids also increased, by 2.08 times in both samples. Thus, it has been scientifically proven that a combination of organic butter and vegetable oil significantly improves the fat-acid composition of flour-based confectionery products.

Given the HACCP principles, a flowchart of production has been compiled, which is the basis for the analysis of hazardous factors. The ranking system has been proposed for the selection of suppliers. The most significant criteria for ranking the organic products manufacturers is the availability of the State registration of the supplier, the implemented HACCP system, the presence of an organic certificate, and the conformity of quality indicators to the requirements of normative documentation. When less than 50 points is collected, a supplier cannot qualify. The obtained scientific data confirm preliminary research, reported in [27], on the HACCP system implementation in the production of bakery products. The data obtained could be used by enterprises making flour-based products in order to improve the food safety management system.

The main drawback of this study is the fact that most Ukrainian enterprises are not yet ready to expand the assortment of the finished organic products. In addition, the production of the proposed formulations involves coconut sugar, lemongrass powder, and organic ginger, which are not cultivated in Ukraine. That is, to produce the proposed products, one must use imported raw materials.

The follow-up study is to examine the safety indicators of the developed products during storage. It is also important to investigate the impact of packaging materials on product preservation.

\section{Conclusions}

1. In order to expand the range of organic flour confectionery products, 2 formulations of cakes with fruit fillers, "Kosmyk" and "Lunik", were developed, whose composition contains only organic raw materials. In order to improve the fat-acid composition, the fat was replaced with sea buckthorn oil.

2. Among the microbiological indicators, we determined the content of MAFAM, BGEC, and bacteria of the genus Salmonella. The content of MAFAM was 100 and $100 \mathrm{CFU}$ per $1 \mathrm{~g}$ for both developed samples; no other microorganisms were found. All samples conform to the national standard of Ukraine for the content of toxic elements and aflatoxin $\mathrm{B}_{1}$.

3. The fatty acid composition of the samples, owing to the introduction of sea buckthorn oil, is better than that in control sample. Thus, the content of saturated fatty acids in both samples decreased by almost twice, whereas the content of monounsaturated fatty acids increased, in the sample "Kosmyk", by 1.78 times, and, in the sample "Lunik", by 1.8 times. The content of polyunsaturated fatty acids also increased by 2.08 times in both samples.

4. Given the HACCP principles, a flowchart of production has been compiled, which is the basis for the analysis of hazardous factors. The ranking system has been proposed to select the suppliers. The most significant criteria for ranking the organic products manufacturers is the availability of the State registration of the supplier, the implemented HACCP system, the presence of an organic certificate, and the conformity of quality indicators to the requirements of normative documentation. When less than 50 points is collected, a supplier cannot qualify. 


\section{References}

1. Mie, A., Andersen, H. R., Gunnarsson, S., Kahl, J., Kesse-Guyot, E., Rembiałkowska, E. et. al. (2017). Human health implications of organic food and organic agriculture: a comprehensive review. Environmental Health, 16 (1). doi: https://doi.org/ 10.1186/s12940-017-0315-4

2. Easdani, M., Khaliduzzaman, Bhuiyan, M. (2013). The Design of HACCP Plan for Potato Chips Plant in Bangladesh. Journal of Environmental Science and Natural Resources, 5 (2), 329-338. doi: https://doi.org/10.3329/jesnr.v5i2.14839

3. Bourn, D., Prescott, J. (2002). A Comparison of the Nutritional Value, Sensory Qualities, and Food Safety of Organically and Conventionally Produced Foods. Critical Reviews in Food Science and Nutrition, 42 (1), 1-34. doi: https://doi.org/ $10.1080 / 10408690290825439$

4. Food safety. World Health Organization. Available at: https://www.who.int/news-room/fact-sheets/detail/food-safety

5. Macfarlane, R. (2013). Etude Environnementale Sanitaire Mauritanie. Available at: https://www.academia.edu/15431341/ Etude_Environnementale_Sanitaire_Mauritanie_2013-05-26_

6. Anant, K., Inchulkar, S., Bhagat, S. (2018). A review article on food poisoning. World Journal of Pharmaceutical and Life Sciences WJPLS, 4 (9), 94-99.

7. Conclusion on the peer review of the pesticide human health risk assessment of the active substance chlorpyrifos (2014). EFSA Journal, 12 (4). doi: https://doi.org/10.2903/j.efsa.2014.3640

8. Derzhavna sluzhba Ukrainy z pytan bezpechnosti kharchovykh produktiv ta zakhystu spozhyvachiv. Available at: http://www. consumer.gov.ua/

9. Toxic hazards. Health and Environment Linkages Initiative. Available at: https://www.who.int/heli/risks/toxics/chemicals/en/

10. Hansen, B., Alrøe, H., Kristensen, E., Wier, M. (2002). Assessment of food safety in organic farming. DARCOF Working Papers no. 52. Available at: https://orgprints.org/206/1/Hansen_organic_food_safety.pdf

11. Trofimtseva, O., Prokopchuk, N. (2018). Orhanichnyi rynok v Ukraini. Available at: https://ukraine.fibl.org/fileadmin/documents-ukraine/publications_presentations/Organic_in_Ukraine_Trofimtseva_Prokopchuk-2017_UA.pdf

12. Galgano, F., Tolve, R., Colangelo, M. A., Scarpa, T., Caruso, M. C., Yildiz, F. (2016). Conventional and organic foods: A comparison focused on animal products. Cogent Food \& Agriculture, 1142818. doi: https://doi.org/10.1080/23311932.2016.1142818

13. Bergamo, P. (2003). Fat-soluble vitamin contents and fatty acid composition in organic and conventional Italian dairy products. Food Chemistry, 82 (4), 625-631. doi: https://doi.org/10.1016/s0308-8146(03)00036-0

14. Barański, M., Średnicka-Tober, D., Volakakis, N., Seal, C., Sanderson, R., Stewart, G. B. et. al. (2014). Higher antioxidant and lower cadmium concentrations and lower incidence of pesticide residues in organically grown crops: a systematic literature review and meta-analyses. British Journal of Nutrition, 112 (5), 794-811. doi: https://doi.org/10.1017/s0007114514001366

15. Tkachenko, A. S. (2015). Formuvannia spozhyvchykh vlastyvostei pechyva tsukrovoho pidvyshchenoi kharchovoi tsinnosti. Lviv, 334 .

16. Lozova, T., Kovalchuk, H. (2013). Commodity research storage new cakes. Visnyk Lvivskoi komertsiinoi akademiyi. Seriya tovaroznavcha, 13, 11-13.

17. Hazard analysis and critical control point (HACCP) system and guidelines for its application. Available at: http://www.fao. org/3/y1579e/y1579e03.htm

18. Vasylenko, H., Dorofieieva, O., Holub, B., Myroniuk, H. (2011). Posibnyk dlia malykh ta serednikh pidpryiemstv miasopererobnoi haluzi z pidhotovky ta vprovadzhennia systemy upravlinnia bezpechnistiu kharchovykh produktiv na osnovi kontseptsiyi NASSR. Kyiv: IIFSQ, AMR SShA, 236. Available at: https://www.studmed.ru/vasilenko-g-dorof-va-o-golub-bmironyuk-g-pos-bnik-dlya-malih-ta-seredn-h-p-dpri-mstv-m-yasopererobno-galuz-z-p-dgotovki-ta-vprovadzhennya-sistemi-upravl-nnya-bezpechn-styu-harchovih-produkt-v-na-osnov-koncepc-nassr_397321e6020.html

19. Zucco, F., Borsuk, Y., Arntfield, S. D. (2011). Physical and nutritional evaluation of wheat cookies supplemented with pulse flours of different particle sizes. LWT - Food Science and Technology, 44 (10), 2070-2076. doi: https://doi.org/10.1016/ j.lwt.2011.06.007

20. Popova, I. V. (2019). Obgruntuvannia vyboru potentsiynoho postachalnyka yak faktora pidvyshchennia stiykosti pidpryiemstva. Available at: http://ena.lp.edu.ua/bitstream/ntb/11454/1/72.pdf

21. Średnicka-Tober, D., Barański, M., Seal, C. J., Sanderson, R., Benbrook, C., Steinshamn, H. et. al. (2016). Higher PUFA andn-3 PUFA, conjugated linoleic acid, $\alpha$-tocopherol and iron, but lower iodine and selenium concentrations in organic milk: a systematic literature review and meta- and redundancy analyses. British Journal of Nutrition, 115(6), 1043-1060. doi: https:// doi.org/10.1017/s0007114516000349

22. Organic Meat and Milk Higher in Healthful Fatty Acids. Available at: https://www.organicvalley.coop/newspress/organicmeat-and-milk-higher-healthful-fatty-acids/ 
23. Ozturkoglu-Budak, S. (2017). A model for implementation of HACCP system for prevention and control of mycotoxins during the production of red dried chili pepper. Food Science and Technology, 37 (suppl 1), 24-29. doi: https://doi.org/ 10.1590/1678-457x.30316

24. Tkachenko, A., Syrokhman, I., Lozova, T., Ofilenko, N., Goryachova, E., Hmelnitska, Y., Shurduk, I. (2019). Development of formulations for sponge cakes made from organic raw materials using the principles of a food products safety management system. Eastern-European Journal of Enterprise Technologies, 1 (11 (97)), 60-70. doi: https://doi.org/10.15587/17294061.2019 .155775

25. Alfven, T., Braun-Fahrlander, C., Brunekreef, B., Mutius, E., Riedler, J. et. al. (2006). Allergic diseases and atopic sensitization in children related to farming and anthroposophic lifestyle - the PARSIFAL study. Allergy, 61 (4), 414-421. doi: https://doi.org/ 10.1111/j.1398-9995.2005.00939.x

26. Kummeling, I., Thijs, C., Huber, M., van de Vijver, L. P. L., Snijders, B. E. P., Penders, J. et. al. (2008). Consumption of organic foods and risk of atopic disease during the first 2 years of life in the Netherlands. British Journal of Nutrition, 99 (3), 598-605. doi: https://doi.org/10.1017/s0007114507815844

27. Marques, N., Matias, J., Teixeira, R Brojo, F. (2012). Implementation of Hazard Analysis Critical Control Points (HACCP) in a SME: Case Study of a Bakery. Polish Journal of Food and Nutrition Sciences, 62 (4), 215-227. doi: https://doi.org/10.2478/ v10222-012-0057-5 